\title{
Pengaruh Kebiasaan Makan dan Aktivitas Fisik Terhadap Kejadian Obesitas pada Remaja di Sekolah Menengah Atas Negeri 1 Kecamatan Kota Juang Kabupaten Bireuen
}

\author{
Effect Of Food Habits And Physical Activities On Obesity Events In \\ Adolescents In Medium School The State 1 Sub-District Kota Juang Bireuen \\ 2018 \\ Ferinawati*1 $^{1}$, Sulis Mayanti ${ }^{2}$ \\ ${ }^{1,2}$ Akademi Kebidanan Munawarah, Jalan Sultan Iskandar Muda, No. 18 Kota Juang, Bireuen \\ *Korespondensi Penulis: Ferinabireuen88@gmail.com
}

\begin{abstract}
Abstrak
Obesitas kini dinyatakan oleh World Health Organization (WHO) sebagai epidemi global, serta menjadi suatu masalah kesehatan yang harus segera ditangani. Obesitas menjadi masalah diseluruh dunia karena prevalensinya yang meningkat pada orang dewasa dan anak baik di negara maju maupun negara berkembang. Tujuan penelitian ini untuk menganalisis kebiasaan makan dan aktivitas fisik pada remaja di SMA Negeri 1 Bireuen Kecamatan Kota Juang Kabupaten Bireuen Tahun 2017. Jenis penelitian adalah kasus-kontrol dengan sampel penelitian adalah remaja SMA Negeri 1 Bireuen Kelas XI dan XII sebanyak 82 sampel masing-masing 41 kasus dan 41 kontrol. Pengambilan sampel dilakukan dengan cara simple random sampling, analisa data dilakukan dengan uji statistik univariat, bivariat dan multivariat menggunakan regresi logistik. Hasil penelitian pada analisa bivariat menunjukkan ada hubungan yang signifikan antara kebiasaan mengkonsumsi sumber energi, kebiasaan mengkonsumsi minuman manis atau soft drink, kebiasaan mengkonsumsi makanan cepat saji, aktivitas fisik, dengan kejadian obesitas poada remaja di Sekolah Menengah Atas Negeri 1 Bireuen. Hasil uji regresi logistik sebagai variabel yang paling dominan yang berpengaruh terhadap kejadian obesitas adalah variabel aktivitas fisik $(\mathrm{OR}=26,725)$. Berdasarkan analisa yang dilakukan ternyata aktivitas fisik memiliki pengaruh paling besar terhadap kejadian obesitas pada remaja di Sekolah Menengah Atas Negeri 1 Kecamatan Kota Juang Kabupaten Bireuen.
\end{abstract}

Kata Kunci : Kejadian Obesitas, Kebiasaan Makan dan Aktivitas Fisik

\begin{abstract}
Obesity is now declared by the World Health Organization (WHO) as a global epidemic, as well as being a health problem that must be addressed. Obesity is a problem throughout the world because of its prevalence is increasing in both adults and children in both the developed and developing countries. This study aimed to analyze the eating habits and physical activity in adolescent in SMAN 1 Bireuen District of Kota Juang, Bireuen Year 2018. The study was a case-control study sample was a teenager with SMAN 1Bireuen Class XI and XII as many as 82 samples each 41 cases and 41 controls. The sampling is done by simple random sampling, data analysis conducted with statistical test univariate, bivariate and
\end{abstract}


multivariate (logistic regression). Results of research on bivariate analysis showed no significant relationship between the habit of consuming energy sources, the habitof consuming sugary drinks or soft drinks, the habit of eating fast food, physical activity, with the variables that influence the incidence of obesity is variable physical activity $(O R=$ 26.725). Based on the analysis carried out it turns out that physical activity has the greatest influence on the incidence of obesity in adolescents in State Senior High School 1, Juang City District, Bireuen District.

Keywords : Genesis Obesity, Eating Habits and Physical Activity

\section{PENDAHULUAN}

Obesitas kini dinyatakan oleh World Health Organization (WHO) sebagai epidemi global, serta menjadi suatu masalah kesehatan yang harus segera ditangani. Obesitas menjadi masalah diseluruh dunia karena prevalensinya yang meningkat pada orang dewasa dan anak baik di negara maju maupun negara berkembang. Jumlah anak usia sekolah dengan obesitas sekitar 10,6 juta jiwa. Penelitian di Amerika menunjukkan 80\% anak remaja obesitas cenderung mengkonsumsi makanan cepat saji (Sulistyoningsih, 2012).

World Health Organization (WHO) tahun 2013 menyatakan bahwa di seluruh dunia ada sekitar 1,6 milyar remaja berumur 15 tahun kelebihan berat badan dan sebanyak 400 juta orang gemuk (obesitas) dan diperkirakan lebih dari 700 juta orang akan menjadi gemuk (obesitas) pada tahun 2015 (WHO, 2013).

Overweight dan obesitas di Amerika Serikat meningkat drastis selama dua dekade terakhir. Menurut National Health and Nutrition Examination Survei 2009-2010, 61\% orang dewasa di Amerika Serikat yang berusia 20 tahun atau lebih tua mengalami overweight atau obesitas, angka ini meningkat 5\% dari yang diperkirakan pada tahun 2004. Penelitian ini juga memperkirakan bahwa $13 \%$ anak berusia 6 sampai 11 tahun dan $14 \%$ remaja berusia 12-19 tahun mengalami overweight (Arisman, 2010).

Prevalensi obesitas mengalami peningkatan pada remaja, baik di negara maju maupun berkembang. Prevalensi overweight dan obesitas meningkat tajam di kawasan Asia Pasifik. Sebagai contoh, 20,5\% dari penduduk Korea Selatan tergolong overweight dan 1,5\% tergolong obesitas. Sebanyak $16 \%$ penduduk mengalami overweight dan $4 \%$ mengalami obesitas di Thailand. Didaerah perkotaan Cina, prevalensi overweight $12 \%$ pada laki-laki dan 14,4\% pada perempuan masing-masing adalah 5,3\% dan 9,8\% (Riskesdas, 2015).

Menurut data Riset Kesehatan Dasar tahun 2013 prevalensi berat badan lebih pada usia 16-18 tahun sebesar 13,5\% dan obesitas sebesar 15,4\%. Berdasarkan jenis kelamin prevalensi 
obesitas penduduk perempuan usia 16-18 tahun 32,9\% naik 18,1\% dari tahun 2007 (13,9\%) dan 17,5\% dari tahun 2010 (15,5\%). Pada laki-laki, prevalensi obesitas usia 16-18 tahun 2013 sebanyak 19,7\% lebih tinggi dari pada tahun 2007 (13,9\%) dan tahun 2010 (7,8\%). Lima belas provinsi dengan prevalensi sangat gemuk diatas prevalensi nasional, yaitu Bangka Belitung, Jawa Tengah, Sulawesi Selatan, Banten, Kalimantan Tengah, Papua, Jawa Timur, Kepulauan Riau, Gorontalo, DI Yogyakarta, Bali, Kalimantan Timur, Sulawesi Utara dan DKI Jakarta (Asrin, 2013).

Penelitian yang dilakukan di Aceh tepatnya di Sekolah Menengah Atas Negeri 2 Banda Aceh menunjukkan 58\% remaja mengalami obesitas, dimana ditemukan hubungan bermakna antara makanan cepat saji dengan kejadian obesitas pada siswa Sekolah Menengah Atas Negeri 2 dengan nilai p value 0,015(6). Seseorang dikatakan menderita obesitas bila berat badan pada laki-laki melebihi $15 \%$ dan pada wanita melebihi $20 \%$ dari berat badan ideal menurut umurnya. Obesitas berisiko bagi penderitanya, untuk terkena diabetes, hipertensi, kolesterol, penyakit jantung koroner, mudah lelah, ketidakseimbangan hormon, gagal ginjal, stroke, aterosklerosis (Proverawati, 2010).

Secara ilmiah, obesitas terjadi akibat mengkonsumsi kalori lebih banyak dari yang diperlukan tubuh. Meskipun penyebab utamanya belum diketahui, namun obesitas pada remaja terlihat cenderung kompleks, multifaktorial, dan berperan sebagai pencetus terjadinya penyakit kronis dan degenerativ. Obesitas dapat terjadi karena berbagai faktor, yaitu faktor genetik, kebiasaan makan, aktifitas fisik, tingkat pendidikan orang tua dan gangguan hormonal (Mukhtiharti, 2010).

Masalah gizi pada remaja timbul karena perilaku gizi yang salah, yaitu ketidak seimbangan antara konsumsi gizi dengan kecukupan gizi yang dianjurkan. Status gizi merupakan gambaran apa yang dikonsumsi dalam jangka waktu yang cukup lama. Keadaan gizi dapat berupa gizi kurang, gizi baik atau gizi normal, maupun gizi lebih (Lingga, 2010).

Terjadinya obesitas pada remaja sering dihubungkan dengan perubahan gaya hidup dan pola makan. Hal ini seiring dengan perkembangan zaman yang menuntun remaja lebih cenderung senang dengan makanan jajanan diluar rumah. Makanan jajanan dalam porsi besar sangat mudah dijumpai di tempat makan junk food seperti hamburger, pizza, kue-kue dan es cream, minuman bersoda dan lain-lain, Di supermarket maupun kantin sekolah juga sangat banyak menyediakan makanan yang mengandung bahan adiktif pangan (BAP) dan residu bahan kimia pertanian makanan modern dianggap "lebih enak atau lebih nikmat". Makanan 
jajanan yang dibeli di luar rumah cenderung mempunyai kandungan yang lebih tinggi dalam energi total, lemak total, kolesterol, lemak jenuh tetapi memiliki kandungan kalsium dan serat yang rendah (Damapoli, 2013).

Peningkatan indeks massa tubuh (IMT) berhubungan dengan bertambahnya resiko terhadap penyakit Diabetes Mellitus tipe 2, penyakit jantung, hipertensi, gangguan saluran pernafasan, osteoarthritis (peradangan sendi), stroke, gangguan kesuburan dan penyakit lainya. Selain berakibat terhadap kesehatan fisik, obesitas juga berdampak pada masalah sosial dan ekonomi. Terkadang dampak terhadap konsekuensi ekonomi masyarakat atau perorangan sering kali tertutup oleh dampak kesehatan dan sosial (Mendrofa, 2012).

Kebiasaan makan merupakan ekspresi setiap individu atau kelompok dalam memilih makanan dan hal ini akan membentuk pola perilaku sehari-hari dalam mengkonsumsi makanan. Seperti kebiasaan makan yang terjadi di kabupaten Bireuen, yang merupakan salah satu Kabupaten yang ada di Aceh, masyarakat Bireuen sendiri memiliki kebiasaan makan yang sudah membentuk suatu pola, hal ini di pengaruhi oleh ketersediaan beberapa jenis makanan yang membuat nafsu makan semakin meningkat, seperti : mie Aceh, sate matang, kuah pliek U, gulai kambing, nasi bebek khas Bireuen, mie pangsit Bireuen dan lain-lain, dalam makanan ini sendiri banyak mengandung lemak, garam, dan juga kalori secara keseluruhan yang dapat memicu seseorang mengalami obesitas (Kusumah, 2010).

Seseorang dengan aktivitas fisik yang kurang dapat meningkatkan prevalensi terjadinya obesitas. Orang-orang yang kurang aktif memerlukan kalori dalam jumlah sedikit dibandingkan orang dengan aktivitas tinggi. Seseorang dengan hidup kurang aktif (Sedentary Life) atau tidak melakukan aktivitas fisik yang seimbang dan mengkonsumsi makanan yang tinggi lemak, akan cenderung mengalami obesitas (Simatupang, 2008).

Penelitian yang dilakukan oleh Damopoli, dkk (2013) pada anak SMP di kota Manado meneliti hubungan kebiasaan makan fast food dengan kejadian obesitas mendapat hasil bahwa variabel yang berhubungan dengan obesitas $(\mathrm{p}=0,024<0,05)$. Kejadian obesitas pada anak laki-laki 44 orang $(32,4 \%)$ dan perempuan 24 orang $(17,6 \%)$, asupan energi fast food pada anak di atas rata-rata dan mengalami obesitas sebesar 33,8\% dan tidak mengalami obesitas sebesar 23,5\% (Damapoli, 2010).

Hasil survei awal yang peneliti lakukan di SMA Negeri 1 Bireuen diketahui bahwa sekolah ini memiliki siswa sebanyak 1054 orang. Berdasarkan penimbangan berat badan dan pengukuran tinggi badan yang peneliti lakukan di dapatkan hasil terdapat 51 siswa yang 
mengalami obesitas, terdiri dari $31(10,19 \%)$ siswa kelas XI, 20 (6,57\%) siswa kelas XII. Dari 51 siswa yang mengalami obesitas 29 diantaranya adalah wanita dan 22 lainnya adalah laki-laki.

Berdasarkan latar belakang diatas maka peneliti tertarik untuk meneliti lebih lanjut mengenai pengaruh kebiasaan makan dan aktivitas fisik terhadap kejadian obesitas pada remaja di Sekolah Menengah Atas Negeri I Bireuen Kecamatan Kota Juang Kabupaten Bireuen Tahun 2018.

Tujuan penelitian ini untuk menganalisis kebiasaan makan dan aktivitas fisik pada remaja di SMA Negeri 1 Bireuen Kecamatan Kota Juang Kabupaten Bireuen Tahun 2018.

\section{METODE PENELITIAN}

Jenis penelitian ini adalah penelitian kuantitatif dengan menggunakan studi analitik observasional. Desain penelitian ini menggunakan desain penelitian kasus kontrol (case control), sering juga disebut retrospektive study.

Lokasi penelitian di lakukan di Sekolah Menengah Atas Negeri 1 Kecamatan Kota Juang Kabupaten Bireuen. Waktu penelitian dimulai dari bulan April sampai dengan mei 2018. Populasi kasus dalam penelitian ini adalah seluruh remaja yang duduk di bangku kelas XI dan XII yang mengalami obesitas di Sekolah Menengah Atas Negeri 1 Bireuen yaitu 51 remaja yang berumur 15-18 tahun. Adapun matching dari populasi penelitian adalah jenis kelamin dan umur.

Metode analisa data menggunakan analisa univariat, analisa Bivariat untuk melihat pengaruh variabel independen dan dependen dengan menggunakan chi-square pada tingkat kemaknaan 95\% atau nilai $(\alpha=0,05)$. Selanjutnya juga mengetahui besar risiko (Ood ratio/OR Nilai besarnya Odds Ratio ditentukan dengan rumus OR = a.d / b.c , dengan Confidence Interval (CI) 95\%, dan analisa multivariat Uji statistik yang digunakan adalah "regresi logistic” pada batas kemaknaan $95 \%$.

\section{HASIL DAN PEMBAHASAN}

\section{Analisis Bivariat}

Berdasarkan tabel 3 dapat dilihat Kejadian obesitas pada remaja merupakan suatu proses kumilatif yang terjadi pada masa kanak-kanak hingga remaja. Pengaruh kebiasaan makan remaja mengkonsumsi sumber energi terhadap kejadian obesitas dapat dilihat 
berdasarkan uji statistik diperoleh nilai hasil uji statistik chi kuadrtar p-value $=0,000$ dengan Odd Ratio (OR) 10,111. Berdasarkan nilai p menunjukkan ada pengaruh antara kebiasaan makan remaja mengkonsumsi sumber energi dengan risiko terjadinya obesitas. Kebiasaan makan remaja mengkonsumsi sumber energi yang tidak baik berisiko $10 \mathrm{kali}$ mengalami obesitas dibandingkan dengan remaja yang mengkonsumsi sumber energi yang baik.

Pengaruh kebiasaan makan remaja mengkonsumsi protein hewani terhadap kejadoian obesitas dapat dilihat berdasarkan uji statistik diperoleh nilai hasil uji statistik chi-kuadrat $p$-value $=$ 0,638 dengan Odd Ratio (OR) 1,394. Berdasarkan nilai p menunjukkan tidak ada pengaruh antara kebiasaan makan mengkonsumsi protein hewani terhadap risiko terjadinya obesitas.

Pengaruh kebiasaan makan remaja mengkonsumsi protein nabati terhadapkejadian obesitas dapat dilihat berdasarkan uji statistik diperoleh nilai hasil uji statistik chi-kuadrat p-value $=0,769$ dengan Odd Ratio (OR) 1,414. Berdasarkan nilai p menunjukkan tidak ada pengaruh antara kebiasaan makan mengkonsumsi protein nabati terhadap risiko terjadinya obesitas.

Pengaruh kebiasaan makan remaja mengkonsumsi sayuran dengan kejadian obesitas dapat dilihat berdasarkan uji statistik diperoleh nilai hasil uji statistik chi-kuadrat p-value = 0,312 dengan Odd Ratio (OR) 1,915. Berdasarkan nilai p menunjukkan tidak ada pengaruh antara kebiasaan makan mengkonsumsi sayuran terhadap risiko terjadinya obesitas.

Pengaruh kebiasaan makan remaja mengkonsumsi buah-buahan terhadap kejadian obesitas dapat dilihat berdasarkan uji statistik diperoleh nilai hasil uji statistik chi-kuadrat p-value $=0,182$ dengan Odd Ratio (OR) 2,414. Berdasarkan nilai p menunjukkan tidak ada pengaruh antara kebiasaan makan mengkonsumsi buah-buahan terhadap risiko terjadinya obesitas.

Pengaruh kebiasaan makan remaja mengkonsumsi minuman manis dan soft drinks terhadap kejadian obesitas dapat dilihat berdasarkan uji statistik diperoleh nilai hasil uji statistik chi-kuadrat p-value $=0,000$ dengan Odd Ratio $(\mathrm{OR})$ 11,022. Berdasarkan nilai $\mathrm{p}$ menunjukkan ada pengaruh antara kebiasaan remaja mengkonsumsi minuman manis dan soft drinks terhadap risiko terjadinya obesitas. Kebiasaan remaja mengkonsumsi minuman manis dan soft drinks yang tidak baik berisiko 11 kali mengalami obesitas dibandingkan dengan remaja yang mengkonsumsi minuma manis dan soft drinks. 
Pengaruh kebiasaan makan remaja mengkonsumsi makanan cepat saji terhadap kejadian obesitas dapat dilihat berdasarkan uji statistik diperoleh nilai hasil uji statistik chikuadrat p-value $=0,000$ dengan Odd Ratio $(\mathrm{OR})$ 5,979. Berdasarkan nilai p menunjukkan ada pengaruh antara kebiasaan remaja mengkonsumsi makanan cepat saji terhadap risiko terjadinya obesitas. Kebiasaan makan remaja mengkonsumsi makanan cepat saji yang tidak baik berisiko 5 kali mengamalami obesitas dibandingkan dengan remaja yang mengkonsumsi makanan cepat saji yang baik.

Aktivitas fisik adalah gambaran mengenai kegiatan fisik yang dilakukan remaja dalam kurun waktu 1×24 jam. Berdasarkan uji statistik diperoleh nilai hasil uji statistik chi-kuadrat $p$-value $=0,000$ dengan Odd Ratio $(\mathrm{OR})$ 6,163. Berdasarkan nilai $\mathrm{p}$ menunjukkan ada pengaruh antara aktivitas fisik terhadap kejadian obesitas. Aktivitas fisik yang ringan 6 kali berisiko mengalami obesitas dibandingkan dengan remaja yang melakukan aktivitas fisik berat.

Tabel 1. Pengaruh Kebiasaan Makan Remaja Mengkonsumsi Sumber Energi, Protein Hewani, ProteinNabati, Sayuran, Buah-buahan, Minuman Manis, Makanan Cepat Saji dan Aktivitas Fisik Dengan Kejadian Obesitas di SMA Negeri 1 Bireuen Tahun 2018

\begin{tabular}{|c|c|c|c|c|c|c|c|c|}
\hline \multirow{3}{*}{ Analisis Bivariat } & \multicolumn{4}{|c|}{ Kejadian } & \multirow{3}{*}{$\mathbf{N}$} & \multirow{3}{*}{ p-Value } & \multirow{3}{*}{ OR } & \multirow{3}{*}{ (CI95\%) } \\
\hline & \multicolumn{2}{|c|}{ Obesitas } & \multicolumn{2}{|c|}{$\begin{array}{c}\text { Tidak } \\
\text { Obesitas }\end{array}$} & & & & \\
\hline & $\mathbf{n}$ & $\%$ & $\mathbf{n}$ & $\%$ & & & & \\
\hline \multirow{2}{*}{$\begin{array}{c}\text { Sumber Energi } \\
\text { Baik (3 kali sehari) } \\
\text { Tidak Baik ( } \geq 3 \text { kali } \\
\text { sehari) }\end{array}$} & 15 & 18,3 & 35 & 42,7 & 50 & \multirow[b]{2}{*}{0,000} & \multirow[b]{2}{*}{10,111} & \multirow[b]{2}{*}{$(3,454-29,601)$} \\
\hline & 26 & 31,7 & 6 & 7,3 & 32 & & & \\
\hline \multirow{2}{*}{$\begin{array}{c}\text { Protein Hewani } \\
\text { Baik (3 kali sehari) } \\
\text { Tidak Baik }(\geq 3 \text { kali } \\
\text { sehari) }\end{array}$} & 26 & 31,7 & 29 & 35,4 & 55 & \multirow[b]{2}{*}{0,638} & \multirow[b]{2}{*}{1,394} & \multirow[b]{2}{*}{$(0,553-3,518)$} \\
\hline & 15 & 18,3 & 12 & 14,6 & 27 & & & \\
\hline \multicolumn{9}{|l|}{ Protein Nabati } \\
\hline $\begin{array}{l}\text { Baik (3 kali sehari) } \\
\text { Baik (3 kali sehari) }\end{array}$ & $\begin{array}{c}33 \\
8\end{array}$ & $\begin{array}{c}40,2 \\
9,8\end{array}$ & $\begin{array}{c}35 \\
6\end{array}$ & $\begin{array}{c}42,7 \\
7,3\end{array}$ & $\begin{array}{l}68 \\
14\end{array}$ & 0,769 & 1,414 & $(0,443-4,513)$ \\
\hline \multirow{2}{*}{$\begin{array}{c}\text { Sayuran } \\
\text { Baik }(\geq 2 \text { kali } \\
\text { sehari) } \\
\text { Tidak Baik }(\leq 2 \text { kali } \\
\text { sehari) }\end{array}$} & 28 & 34,1 & 33 & 40,2 & 61 & \multirow{2}{*}{0,312} & \multirow{2}{*}{1,915} & \multirow{2}{*}{$(0,694-5,282)$} \\
\hline & 13 & 15,9 & 8 & 9,8 & 21 & & & \\
\hline \multirow{3}{*}{$\begin{array}{c}\text { Buah-Buahan } \\
\text { Baik }(\geq 1 \text { kali } \\
\text { sehari) } \\
\text { Tidak Baik (tidak } \\
\text { sama sekali) }\end{array}$} & & & & & & \multirow{3}{*}{0,182} & \multirow{3}{*}{2,414} & \multirow{3}{*}{$(0,806-7,227)$} \\
\hline & 29 & 14,6 & 35 & 42,7 & 64 & & & \\
\hline & 12 & 29,3 & 6 & 7,3 & 18 & & & \\
\hline
\end{tabular}




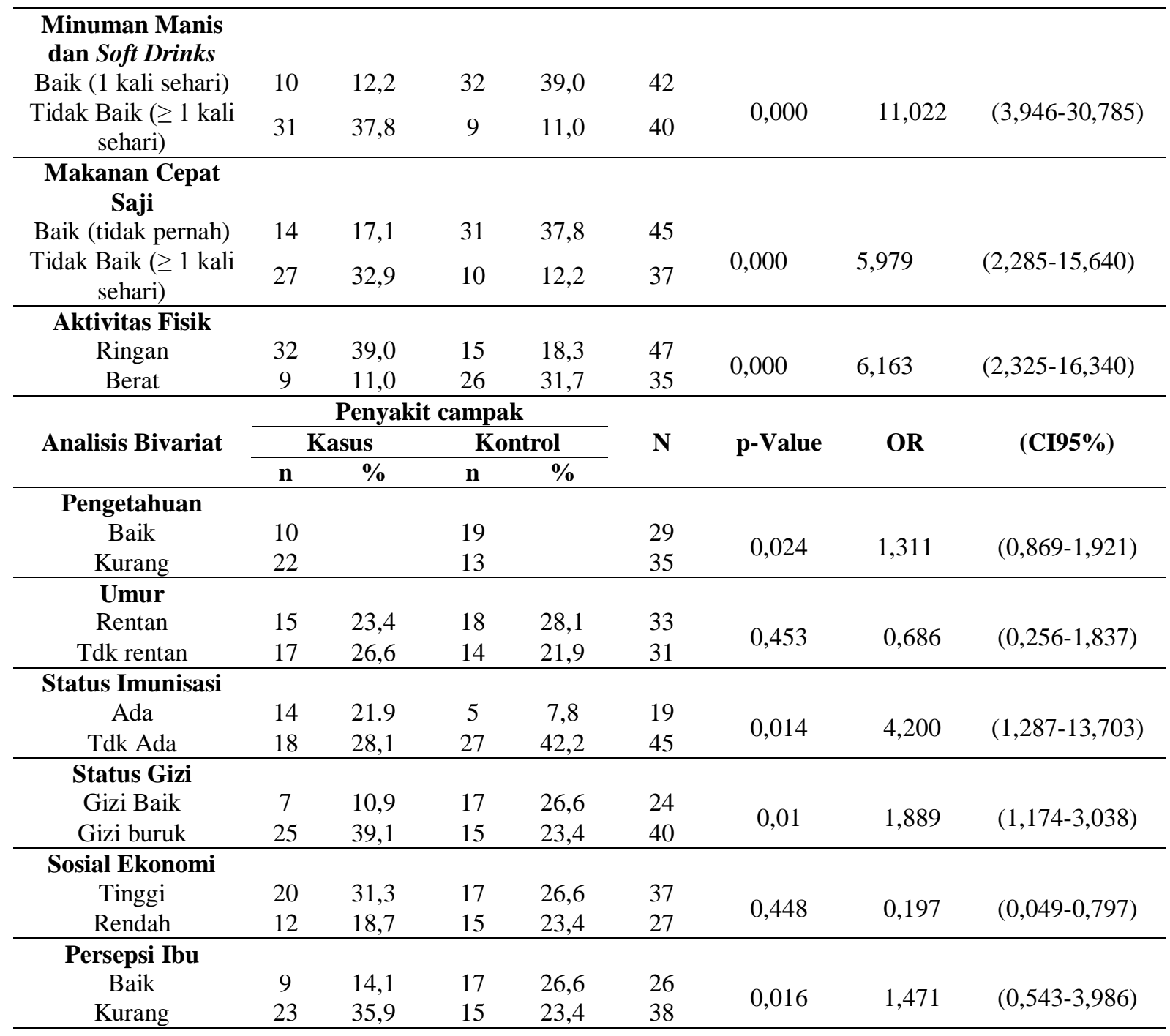

\section{Analisis Multivariat}

Berdasarkan tabel 4 menunjukkan bahwa variabel aktivitas fisik, makanan cepat saji, sumber energi dan minuman manis dan soft drinks merupakan variabel yang signifikan $(\mathrm{p}<0,05)$ terhadap kejadian obesitas. Dengan demikian gambaran diatas merupakan permodelan yang paling sesuai dalam penelitian ini. 
Tabel 2. Analisa Pengaruh Kebiasaan Makan Mengkonsumsi Sumber Energi, Minuman Manis, Makanan Cepat Saji, Dan Aktivitas Fisik Remaja Terhadap Kejadian Obesitas Pada Remaja Di SMA Negeri 1 Bireuen Tahun 2018

\begin{tabular}{llcccc}
\hline No & \multicolumn{1}{c}{ Variabel } & $\boldsymbol{\beta}$ & p-Value & Exp (B) & $\begin{array}{c}\text { CI95\% (Lower- } \\
\text { Upper) }\end{array}$ \\
\hline 1 & Aktivitas Fisik & 3,286 & 0,000 & 6,163 & $2,325-16,340$ \\
2 & $\begin{array}{l}\text { Makanan Cepat } \\
\text { Saji }\end{array}$ & & 0,000 & 5,979 & $2,285-15,640$ \\
3 & Sumber Energi & 1,675 & 0,003 & 5,340 & $1,143-24,935$ \\
4 & minuman manis & 1,640 & 0,000 & 11,022 & $3,946-30,785$ \\
\hline & Constant & $-4,465$ & 0,000 & 0,012 & $0,806-7,227$ \\
\hline
\end{tabular}

Overall Percentage $=79,7$

\section{Pembahasan}

1. Pengaruh Kebiasaan Makan Remaja Terhadap Kejadian Obesitas

Kejadian obesitas merupakan hal kompleks yang terjadi akibat berbagai faktor diantaranya adalah kebiasaan makan yang tidak baik yang tidak diimbangi dengan aktivitas fisik yang baik. Hal ini dapat dilihat sebagai besar responden memiliki status gizi normal yaitu sebanyak 75,0 \% siswa, 3,0 \% siswa berada pada kategori kurus, 14,2 \% siswa berada pada kategori gemuk dan 7,8\% berada pada kategori obesitas.

Riwayat kebiasaan makan remaja dikaji melalui jenis makanan dan frekuensi makanan yang dikonsumsi oleh remaja setiap hari. Hasil uji Chi-square menunjukkan dari ketujuh jenis kebiasaan makan tersebut hanya tiga jenis makanan yang signifikan terhadap kejadian obesitas $(\mathrm{p}<0,05)$ yaitu kebiasaan makan remaja mengkonsumsi protein hewani, kebiasaan makan remaja mengkonsumsi protein nabati, kebiasaan makan remaja mengkonsumsi sayuran dan kebiasaan makan remaja mengkonsumsi buah-buahan. Dimana untuk kebiasaan mengkonsumsi sumber energi yang tidak baik berpeluang sebesar 10 kali terjadi pada remaja yang obesitas (OR $=10,111$ pada 95\% CI: 3,454-29,601), sedangkan untuk kebiasaan mengkonsumsi minuman yang tidak baik berpeluang sebesar 11 kali terjadi pada remaja yang obesitas ( $\mathrm{OR}=11,022$ pada 95\% CI: 3,946-30,785). Demikian juga untuk kebiasaan mengkonsumsi makanan cepat saji yang sering berpeluang sebesar 5 kali terjadi pada remaja yang obesitas ( $\mathrm{OR}=5,979$ pada $95 \% \mathrm{CI}: 2,285-15,640)$. 
2. Pengaruh Kebiasaan Makan Remaja Mengkonsumsi Makanan Cepat Saji Terhadap Kejadian Obesitas

Salah satu yang menjadi masalah serius dalam kasus obesitas adalah kebiasaan mengkonsumsi makanan olahan yang mengandung gula, lemak serta zat adiktif menyebabkan remaja mengalami perubahan patologis secara dini (Arisman, 2010).

Hasil penelitian ini sejalan dengan penelitian Liesnawati (2007) di SMU Harapan 1 Medan ditemukan adanya hubungan yang signifikan antara konsumsi fast food dengan status gizi, khususnya pada penderita obesitas (Zulfa, 2001). Begitu juga dengan penelitian yang dilakukan oleh Damapoli dkk (2013) di Manado yang menunjukkan bahwa terdapat hubungan antara konsumsi fast food dengan terjadinya obesitas (Mendrofa, 2012).

Adanya pengaruh tersebut sesuai dengan pendapat Soetjiningsih (2007) bahwa obesitas dapat terjadi kalau asupan kaloro berlebihan. Ditambah lagi gaya hidup masa kini yang suka mengkonsumsi fast food yang berkalori tinggi seperti berbagai jenis olahan ayam dan aneka makanan mie (Wirakusumah, 2006).

Hal ini sejalan dengan pendapat Zulfa (2011) yang menyatakan bahwa konsumsi yang tinggi terhadap fast food (makanan siap saji) dapat menyebabkan terjadinya gizi lebih atau kegemukan (obesitas) karena kandungan dari makanan cepat saji tersebut tinggi kalori, tinggi lemak dan rendah serat (Zulfa, 2001).

Menurut asumsi peneliti dengan melihat hasil penelitian menyimpulkan bahwa responden sering mengkonsumsi makanan cepat saji sehingga mereka mengalami obesitas, dikarenakan makanan cepat saji mengandung kalori yang tinggi. Kebiasaan remaja sering mengkonsumsi makanan cepat saji disebabkan karena remaja tidak sarapan pada pagi hari sehingga menjelang siang hari mereka jajan dikantin yang menyediakan mie pangsit, bakso dan mie instan. Selain itu, padatnya jadwal disekolah dan sering berkumpul dengan teman menyebabkan remaja lebih memilih makanan cepat saji. Jenis makanan cepat saji yang paling di sukai oleh responden adalah mie bakso, mie pangsit, nasi gurih, mie instan, nasi goreng, ayam lepas/penyet dan gorengan.

3. Pengaruh Kebiasaan Makan Remaja Mengkonsumsi Sumber Energi Terhadap Kejadian Obesitas

Gaya hidup modern saat ini cendrung menyebabkan status gizi pada anak dan remaja diatas normal, sehingga remaja menjadi gemuk dan obesitas. Hal ini disebabkan karena 
perilaku makan yang salah diantaranya banyak makan namun kurang beraktifitas sehingga energi yang masuk kedalam tubuh jauh lebih banyak daripada energi yang digunakan untuk aktivitas dan pertumbuhan. Kelebihan energi ini akan disimpan dalam tubuh dalam bentuk lemak dan lama kelamaan akan menyebabkan terjadinya obesitas (WHO, 2013).

Pada penelitian ini remaja memiliki asupan sumber energi sederhana yang berlebih seperti minuman kemasan, kue manis dan es krim. Asupan energi yang berasal dari lemak, karbohidrat, dan protein yang melebihi kebutuhan tubuh akan disimpan dalam bentuk lemak dan glikogen yang disimpan di jaringan adipose, proses ini dinamakan lipoginesis yaitu proses pembentukan lemak dari non lemak. Semakin banyak asupan energi dari non lemak maka simpanan lemak pada jaringan adipose semakin banyak (Zulfa, 2001).

Hasil penelitian ini sejalan dengan teori yang menyatakan bahwa asupan energi yang berlebih merupakan penyebab utama terjadinya kegemukan (obesitas) energi diperoleh dari metabolisme zat gizi didalam tubuh. Jenis zat gizi yang dikonsumsi oleh tubuh antara lain protein, karbohidrat dan lemak. Proses dan jumlah energi yang dihasilkan oleh masingmasing zat gizi ini berbeda satu dengan yang lainnya. Makanan yang padat energi yang disertai dengan kurangnya katifitas fisik diduga akan mengakibatkan berat badan akan bertambah, dan sebagian besar kelebihan energi tersebut akan disimpan sebagai lemak dan penumpukan lemak inilah yang menyebabkan obesitas. Hasil penelitian ini sesuai dengan hasil penelitian Terry Ayufrianti (2010) yang menyatakan ada hubungan antara asupan energi dengan kejadian obesitas (Liesnawati, 2007).

Menurut asumsi peneliti dengan melihat hasil penelitian menyimpulkan bahwa responden mengkonsumsi sumber energi $\geq 3$ kali sehari sehingga mereka cenderung mengalami obesitas. Kebiasaan sumber energi yang dikonsumsi remaja adalah nasi dan mie karena nasi dan mie adalah makanan yang mengenyagkan menurut remaja di Sekolah Menengah Atas Negeri 1 Bireuen. Banyak remaja yang akan merasa tidak kenyang jika tidak makan nasi atau mie, hal ini tidak salah, karena sumber energy manusia berasal dari karbohidrat dan karbohidrat banyak terdapat dalam nasi. Sayangnya kebutuhan karbohidrat tubuh untuk dibuat menjadi energi kadang tidak sebesar asupan kita pada umumnya. Sering mengkonsumsi sumber energi justru membuat tubuh kelebihan karbohidrat dan hal ini tidak baik bagi tubuh. 
4. Pengaruh Kebiasaan Remaja Mengkonsumsi Minuman Manis dan Soft Drink Terhadap Kejadian Obesitas

Soft Drink adalah minuman yang berkarbonasi yang diberi tambahan berupa bahan perasa dan pemanis seperti gula. Soft Drink terdiri dari sugar-sweetened Soft Drink dan non sugar Soft Drink. Sugar-sweetened Soft Drink merupakan Soft Drink dengan zat pemanis yang berasal dari gula, sedangkan non sugar Soft Drink merupakan Soft Drink dengan zat pemanis yang berasal dari pemanis buatan.

Minum minuman bersoda kalau hanya sekali saja mungkin tidak menjadi masalah, tetapi bila sering meminumnya maka akan memberikan dampak kecanduan atau ketagihan yang akhirnya memberikan dampak yang buruk bagi yang meminumnya. kebanyakan minuman bersoda memiliki kadar gula yang tinggi, dan gula dapat melepaskan seretonin (suatu senyawa yang dapat meningkatkan mood seseorang sehingga orang tersebut merasa bahagia). Jadi tidak heran jika orang yang sering minum minuman bersoda mengalami kenaikan berat badan atau bahkan mengalami kegemukan.

Soda tidak punya nilai gizi selain kandungan kalori dan gulanya yang tinggi. Sebagian besar minuman soda mengandung 250 kalori per $600 \mathrm{ml}$. Tidak ada kandungan nutrisi atau mineral didalamnya, melainkan hanya gula dan kafein.

Remaja cenderung mengkonsumsi soft drink untuk menciptakan citra diri yang modern dalam komunitasnya (Kusmiran, 2012). Hasil ini sesuai dengan penelitian Nurhanifah (2008) di kota Yogyakarta menunjukkan bahwa seringnya mengkonsumsi soft drink dan minuman manis berpengaruh terhadap kejadian resistensi insulin dan obesitas pada remaja.

Menurut asumsi peneliti dengan melihat hasil penelitian menyimpulkan bahwa responden sering mengkonsumsi minuman manis dan soft drink sehingga mereka cendrung mengalami obesitas, dikarenakan minuman manis dan soft drink banyak mengandung gula. Kebiasaan remaja sering mengkonsumsi minuman manis dan soft drink disebabkan karena soft drink yang manis dan menyegarkan yang menyebabkan remaja menjadi ketagihan dan juga tersedia dimana saja termasuk di kantion sekolah. Jenis soft drink yang paling disukai oleh responden adalah coca-cola, fanta, sprite, pepsi dan lain sebagainya.

Pihak sekolah belum maksimal dalam menjalankan upaya kesehatan remaja khususnya mengenai permasalahn obesitas pada remaja. Kegiatan promosi kesehatan dan pendidikan kesehatan ataupun penyuluhan kesehatan tentang bahaya obesitas belum 
dilakukan secara maksimal. Pihak sekolah bersama dengan pihak kesehatan terkait hendaknya menggalakkan dan menyediakan fasilitas tentang dampak dari obesitas, misalnya menyediakan waktu untuk penyuluhan kesehatan, memasang standing banner, poster dan lainnya. Selama ini belum pernah dilakukan penyuluhan sebagai upaya pendidikan kesehatan khususnya dalam hal mencegah kejadian obesitas pada remaja.

\section{Pengaruh Aktivitas Fisik Terhadap Kejadian Obesitas}

Hasil penelitian menunjukkan bahwa terdapat perbedaan penggunaan waktu untuk aktivitas fisik antara kelompok remaja yang obesitas dengan yang tidak obesitas ( $\mathrm{p}<$ $0,05)$, terutama menyangkut penggunaa waktu untuk aktivitas ringan dan aktivitas berat. Hal ini menunjukkan bahwa aktivitas fisik yang buruk berpengaruh terhadap kejadian obesitas. Kejadian obesitas merupakan hal kompleks yang terjadi akibat berbagai faktor diantaranya kurangnya aktivitas fisik yang remaja lakukan. Hasil penelitian menunjukkan aktivitas fisik remaja pada kelompok kasus mayoritas ringan yaitu sebesar 78,0\%, dan kategori berat sebesar 22,0\%. Pada kelompok kontrol dapat dilihat bahwa 36,6\% remaja memiliki aktivitas fisik ringan, dan aktivitas fisik berat sebesar $63,4 \%$.

Berdasarkan uji statistik diperoleh nilai hasil uji statistik chi-kuadrat $p$-value $=$ 0,000 dengan OR 6,163 (95\% CI: 2,325-16,340). Berdasarkan nilai p menunjukkkan ada pengaruh antara aktivitas fisik dengan kejadian obesitas. Aktivitas fisik yang ringan 6 kali berisiko mengalami obesitas dibandingkan dengan remaja yang melakukan aktivitas fisik berat. Aktivitas fisik sehari-hari menjadi salah satu faktor munculnya obesitas pada seseorang. Penelitian yang dilakukan oleh Veugelerls dan Fitzgerald menununjukkan bahwa kebiasaan remaja untuk menonton televisi sambil makan dapat meningkatkan resiko seseorang menderita obesitas.

Menurut Meenu dan Madhu (2001), menyatakan bahwa kehilangan aktivitas fisik, akibat menonton televisi atau bermain video game lebih dari 1 (satu) jam setiap hari memiliki kontribusi yang signifikan terhadap obesitas pada anak(37). Lebih jauh dikatakan oleh Musaiger (2004) bahwa perubahan gaya hidup dan status sosial ekonomi di negara-negara Mediternia Timur, berdampak pada aktivitas fisik. Ketersediaan kendaraan, peningkatan peralatan elektrikal rumah tangga menyebabkan hidup lebih santai (Subardja, 2004). 
Aktivitas fisik yang sesuai, aman dan efektif dalam upaya menurunkan berat badanb adalah dengan berolahraga, karena akan membantu memelihara berat badan yang optimal. Gerak yang dilakukan saat berolahraga berbeda dengan gerak saat menjalankan aktivitas sehari-hari seperti berdiri, duduk atau hanya menggunakan tangan, hal ini merupakan gerak anggota badan yang tidak seimbang. Gaya hidup yang kurang menggunakan aktivitas fisik akan berpengaruh terhadap kondisi tubuh seseorang. Aktivitas fisik tersebut diperlukan untuk membakar energi dari dalam tubuh. Apabila pemasukan energi berlebihan dan tidak diimbangi dengan aktivitas fisik akan memudahkan seseorang memiliki berat badan berlebih.

Aktivitas fisik remaja sebagian besar berada pada kategori ringan, hal ini tidak terlepas dari status sebagai pelajar, dimana para orang tua tidak membebankan pekerjaan berat kepada anaknya. Hal ini terlihat dari hampir seluruh remaja laki-laki tidak melakukan pekerjaan rumah baik menyapu, mencucu piring maupun mencuci pakaian, sementara pada wanita mereka hanya dibebankan menyapu rumah 1 kali dalam sehari. Kurangnnya aktivitas yang dilakukan remaja secara tidak langsung berdampak pada kesehatan remaja khususnya pada kejadian obesitas.

\section{Faktor Risiko Yang Paling Dominan Terhadap Kejadian Obesitas}

Untuk mengetahui faktor-faktor apa saja yang diduga sebagai pencetus terjadinya obesitas pada remaja di Sekolah Menengah Atas Negeri 1 Bireuen dilakukan uji regresi logistik dan ternyata menunjukkan hasil yang signifikan $(\mathrm{p}<0,05)$ untuk faktor kebiasaan makan mengkonsumsi sumber energi, minuman manis dan soft drink, makanan cepat saji dan aktivitas fifik. Hasil analisa regresi menunjukkan semakin tinggi faktor-faktor tersebut, semakin tinggi peluang untuk terjadinya obesitas.

Berdasarkan keseluruhan proses analisa yang telah dilakukan dapat disimpulkan bahwa dari kedelapan faktor yang diduga berpengaruh terhadap kejadian obesitas pada remaja di Sekolah Menengah Atas Negeri 1 Bireuen, ternyata ada empat faktor yang secara signifikan berpengaruh terhadap kejadian obesitas pada remaja di Sekolah Menengah Atas Negeri 1 Bireuen.

Remaja yang obesitas berpeluang terjadi obesitas sebesar 26 kali (95\% CI: 1,56846,390) apabila mengkonsumsi makanan cepat saji $\geq 1$ kali sehari setelah dikontrol oleh aktifitas fisik, sumber energi, dan minuman manis dan soft drink. demikian juga remaja 
yang obesitas berpeluang terjadi obesitas sebesar 5 kali (95\% CI: 1,143-24,935) apabila mengkonsumsi sumber energi $\geq 3$ kali sehari setelah dikontrol oleh aktivitas fisik, makanan cepat saji dan minuman manis dan soft drink. Selanjutnta remaja yang obesitas berpeluang terjadi obesitas sebesar 5 kali (95\% CI: 1,103-24,092) apabila mengkonsumsi minuman manis dan soft drink $\geq 1$ kali sehari setelah dikontrol oleh aktifitas fisik, makanan cepat saji dan kebiasaan mengkonsumsi sumber energi.

\section{KESIMPULAN}

Berdasarkan hasil penelitian dan pembahasan yang telah dijelaskan pada bab-bab sebelumnya, kesimpulan yang dapat ditarik dan penelitian ini adalah faktor yang berpengaruh terhadap kejadian obesitas remaja di Sekolah Menengah Atas Negeri 1 Kecamatan Kota Juang Kabupaten Bireuen adalah aktivitas fisik, kebiasaan makan remaja mengkonsumsi makanan cepat saji, kebiasaan makan remaja mengkonsumsi sumber energi dan kebiasaan remaja mengkonsumsi minuman manis dan soft drink, Sedangkan faktor kebiasaan makan remaja mengkonsumsi protein hewani, kebiasaan remaja mengkonsumsi protein nabati, kebiasaan remaja mengkonsumsi sayuran dan kebiasaan remaja mengkonsumsi buah tidak mempengaruhi kejadian obesitas, berdasarkan analisa yang dilakukan ternyata aktivitas fisik memiliki pengaruh yang paling besar terhadap kejadian obesitas pada remaja di Sekolah Menengah Atas Negeri 1 Kecamatan Kota Juang Kabupaten Bireuen.

\section{SARAN}

Diharapkan kepada pihak sekolah dapat menggiatkan kembali monitoring status gizi anak sekolah terutama remaja di Sekolah Menengah Atas Negeri 1 Bireuen untuk memantau pertumbuhan dan perkembangan status gizinya, hal ini dapat dilakukan melalui Program Usaha Kesehatan Sekolah (UKS) yang telah ada, mengadakan penyuluhan-penyuluhan mengenai gizi dan kesehatan termasuk pola hidup sehat kepada remaja di Sekolah Menengah Atas Negeri 1 Bireuen, melakukan penyuluhan tentang gizi secara berkala baik kepada siswa maupun orang tua siswa, dengan materi penyuluhan antara lain : masalah gizi lebih, termasuk cara pencegahan dan penanggulangannya, dampak yang diakibatkan, pemilihan makanan jajanan yang sehat, pola konsumsi yang sehat, memperbanyak konsumsi sayuran dan buahbuahan, dan pentingnya kebiasaan berolahraga. 


\section{DAFTAR PUSTAKA}

Adriani dkk. Peranan Gizi Dalam Siklus Kehidupan. Jakarta: Kencana;2012.

Alamsyah. Antisipasi Krisis Global, Bisnis Fast Food. Jakarta: Kompas Gramedia;2009.

Amelia AH. Perilaku Makan Khas Remaja. [internet]; 2013 [Diakses oleh: Ferinawati, tanggal : 26 oktober 2016].Tersedia diwww.kompas.com/perilaku-makan-khas-remaja.

Ana Medawati, Hanan Hadi, I.D.P. Pramantara, 2005. Hubungan Antara Asupan Energi Asupan Lemak dan Obesitas pada Remaja SLTP di Kota Yogyakarta dan di Kabupaten Bantul, Jurnal Gizi Klinik Indonesia.

Arisman. Gizi Dalam Daur Kehidupan. Jakarta: EGC; 2010.

Asrin. Pengaruh Konsumsi Fast Food Terhadap Kejadian Obesitas Pada Remaja Putri SMAN 2 Kota Banda Aceh.[internet]; 2013. [Diaksesoleh : Ferinawati, 19 April 2015]. Tersedia di http://www.journal-nursing.go.id.

Barasi ME. At a Glance Ilmu Gizi. Jakarta: Erlangga; 2007.

Bustan, M.N., Pengantar Epidemiologi. 2 ed. Jakarta: Penerbit Rineka Cipta;2006.

Damopoli. Hubungan Konsumsi Fast Food Dengan Kejadian Obesitas Pada Anak SD di Kota Manado. Universitas Sam Ratulangi Manado. 2013. e.Journal Keperawatan (eKp).1(1). 1

Elisabeth P, M.B.P\& Emy H.Asupan Energi, Aktivitas Fisik, Persepsi Orang Tua, dan Obesitas Siswa dan Sisiwi SMP di Kota Yogyakarta. Jurnal Gizi Klinik Indoneisa. 2009. 5, No. 3: p. 108-113.

Kawuwung KS. Hubungan Obesitas Dengan Citra Tubuh dan Harga Diri Pada Remaja Putri Program Studi Ilmu Keperawatan Fakultas Kedokteran Universitas Sam Ratulangi Manado.e-journal Keperawatan (e-Kp).2015;3(2):1-6

Kepmenkes RI No. 1995/Menkes/SK/XII/2010. IMT berdasarkan umur; 2010

Kusumah. Diet Ala Rasulullah. Quantum Media: Jakarta; 2010.

Kusmiran. Kesehatan Reproduksi Remaja dan Wanita. Jakarta: Salemba Medika; 2012.

Lingga. Gampang dan Pasti Langsing. Jakarta: PT. Agro Media; 2010.

Liesnawati, M. 2007. Hubungan Konsumsi Fast Food dengan Status Gizi Remaja di SMU Harapan 1 Medan. Skripsi. Medan: FKM USU

Manuaba. Ilmu kebidanan. Jakarta: Yayasan Bina Pustaka;2012.

Mendrofa. Faktor Yang Berhubungan Dengan Kejadian Obesitas Pada Remaja Di SMAN 1 Medan Tahun 2012. Ejournal keperawatan (e-Kp) 2(2).1; 2012.

Meenu Singh, Madhu Sharma, 2005. Risk Factors For Obesity In Children, Departement Of Pediatrics, Advanced Pediatric Center Post Graduate, Institute Of Medical Education and Research, Chandigarh, India.

Misnadiarly. 2007. Obesitas: Sebagai Faktor Risiko Beberapa Penyakit. Jakarta: Pustaka Obor Populer.

Moore. Terapi Diet Dan Nutrisi. Jakarta: Hipokrates; 2007.

Mukhtiharti, dkk. faktor Resiko Kejadian Obesitas Pada Remaja SMA Negeri 2 dan SMA Negeri 3 di Kota Pekalongan Tahun 2010. Poltekkes Kemenkes Semarang. Pekalongan. e-journal keperawatan (e-Kp). 12:1.1-2. 
Muhammad, I. Pemanfaatan SPSS dalam Penelitian Bidang Kesehatan. Bandung: Citra Pustaka Media Perintis: 2012 Willian dan Wilkins. Ilmu Gizi Menjadi Sangat Mudah. Jakarta: EGC; 2012.

Notoatmodjo. Promosi Kesehatan Teori dan Aplikasi. Jakarta: PT. Rineka Cipta; 2010.

Nurhanifah, R.2008. Hubungan Antara Konsumsi Soft Drink Dengan Resistensi Insulin Pada Remaja SMP Obesitas. Universitas Gadjah Mada Yogyakarta.

Proverawati. Obesitas dan Gangguan Perilaku Makan Pada Remaja. Yogyakarta: Nuha Medika; 2010.

Riskesdas. Riset Kesehatan Dasar (Angka Gizi Lebih). Dinkes Aceh; 2015.

Santoso. Terapi Gizi dan Diet Rumah Sakit. Jakarta: EGC; 2010.

Sudigdo, S. Dasar-dasar Metodelogi Penelitian Klinis. Jakarta: SagungSeto;2011.

Sulistyoningsih. Kesehatan Ibu dan Anak. Yogyakarta: Graha Ilmu; 2012

Subardja, D. (2004). Obesitas Primer Pada Anak. Bandung: PT. Kiblat Buku Utama.

Soegih RR. Obesitas Permasalahn dan Terapi Praktis. Jakarta: Sagung Seto; 2013.

Soetjiningsih. 2007. Buku Ajar Tumbuh Kembang Remaja dan Permasalahannya. Jakarta: Sagung Seto.

Suproyanto A. Obesitas, Faktor Penyebab, dan Bentuk-bentuk Terapinya. Yogyakarta. Universitas Negeri Yogyakarta; 2013.

WHO. Health Topic About Obesity. Geneva: World Health Organization; 2013

Wirakusumah, E.2006. Cara Aman dan Efektif Menurunkan Berat Badan. Jakarta: Gramedia Pustaka Utama

Yatim F. Kendalikan Obesitas dan Diabetes: Menhatur Pola Hidup dan Pola Makan. Jakrta: Infocamp; 2010.

Zulfa, F. (2001). Hubungan Kebiasaan Konsumsi Fast Food Modern dengan Status Gizi. (diakses 31 juli 2017) 